\title{
3D model related to the publication: New data on the Miocene dormouse Simplomys García-Paredes, 2009 from the peri-alpin basins of Switzerland and Germany: palaeodiversity of a rare genus in Central Europe
}

\author{
Lu Xiaoyu ${ }^{1 *}$, Maridet Olivier ${ }^{1}$, Jérôme Priéto ${ }^{2}$ \\ ${ }^{1}$ Jurassica Museum, Route de Fontenais 21, CH-2900 Porrentruy, Switzerland / Département des Géosciences, Université de Fribourg, Chemin du \\ Musée 6, CH-1700 Fribourg, Switzerland \\ ${ }^{2}$ Department of Earth- and Environmental Science, Palaeontology, Ludwig-Maximilians-University Munich, Richard-Wagner-Str. 10, 80333 Munich, \\ Germany
}

${ }^{*}$ Corresponding author: 610243584@qq.com

\begin{abstract} Central Europe. https://doi.org/10.1007/s12549-018-0339-y

\section{Specimen \\ Simplomys hugi \\ (MJSN-GLM017-0001) \\ Description \\ Left maxilla with DP4, P4, \\ M1 and M2 teeth}

This contribution contains the 3D model of the holotype of Simplomys hugi, the new dormouse species from the locality of Glovelier described and figured in the following publication: New data on the Miocene dormouse Simplomys García-Paredes, 2009 from the peri-alpin basins of Switzerland and Germany: palaeodiversity of a rare genus in

Keywords: Early Miocene, Gliridae, Maxilla, Simplomys, Switzerland

Submitted:2019-01-11, published online:2019-05-13. https://doi.org/10.18563/journal.m3.83 produced in Amira 6.0 (FEI).
Table 1. The new glirid species (collection: Jurassica Museum).

\section{INTRODUCTION}

The genus Simplomys, a dormouse with a simple dental morphology, was erected by García-Paredes in García-Paredes et al. (2009). The 3D model presented here has been described by Prieto et al. (2018), and is the holotype of the newly described taxon Simplomys hugi, from the Early Miocene of Glovelier, Switzerland. The left Maxilla MJSN-GLM017-0001 (Fig. 1) shows the decidual fourth premolar (DP4) with the unerupted permanent premolar (P4) just below, and first and second molars (M1 and M2); it is deposited in the JURASSICA Museum in Porrentruy (Canton of Jura, Switzerland). This new mediumsized Simplomys is unique by its weak precingulum which is always present on M1 and never found in any other glirids. This genus shows a continuous evolution in Spain during the early Miocene, at the end of the Ramblian and up to the middle Aragonian (García-Paredes et al. 2009, 2016), but its record is in contrast extremely scarce in the corresponding interval in central Europe. Thus, this specimen is of particular importance for the evolution of Simplomys, but also for the understanding of faunal exchanges in Europe.

\section{METHODS}

The 3D model was produced by using the Bruker Skyscan 2211 CT scanner in University of Fribourg. It was CT-scanned with beam energy of $180 \mathrm{kV}$ and a flux of $90 \mu \mathrm{A}$ at a detector resolution of $2.5 \mu \mathrm{m}$ per pixel using a $360^{\circ}$ rotation with a step size of $0.2^{\circ}$ and an aluminum filter. The 3D reconstruction was

\section{ACKNOWLEDGEMENTS}

Grant sponsor: Swiss National Science Foundation. Grant number : 200021-162359. SYNTHESYS Project (ES-TAF-6008), Paléontologie A16.

\section{BIBLIOGRAPHY}

García-Paredes, I., Peláez-Campomanes, P., Álvarez-Sierra, M. A. 2009. Gliridae (Rodentia, Mammalia) with a simple dental pattern: a new genus and new species from the European Early and Middle Miocene. Zoological Journal of the Linnean Society, 157, 622-652. https://doi.org/10.1111/j.10963642.2009.00527.x

García-Paredes, I., Álvarez-Sierra, M. Á., Hoek Ostende, L. W. van den, Hernández Ballarín, V., Hordijk, K., López Guerrero, P., Oliver Pérez, A., Peláez-Campomanes, P. 2016. The Aragonian and Vallesian high-resolution micromammal succession from the Calatayud-Montalbán Basin (Aragón, Spain). Comptes Rendus Palevol, 15, 753-762. https://doi.org/10.101 6/j.crpv.2015.09.014

Prieto, J., Lu, X. Y., Maridet, O., Becker, D., Pirkenseer, C., Rauber, G., \& Peláez-Campomanes, P. 2018. New data on the Miocene dormouse Simplomys García-Paredes, 2009 from the peri-alpin basins of Switzerland and Germany: palaeodiversity of a rare genus in Central Europe. Palaeobiodiversity and Palaeoenvironments, 1-17. https://doi.org/10.1007/s12549-01 8-0339-y 

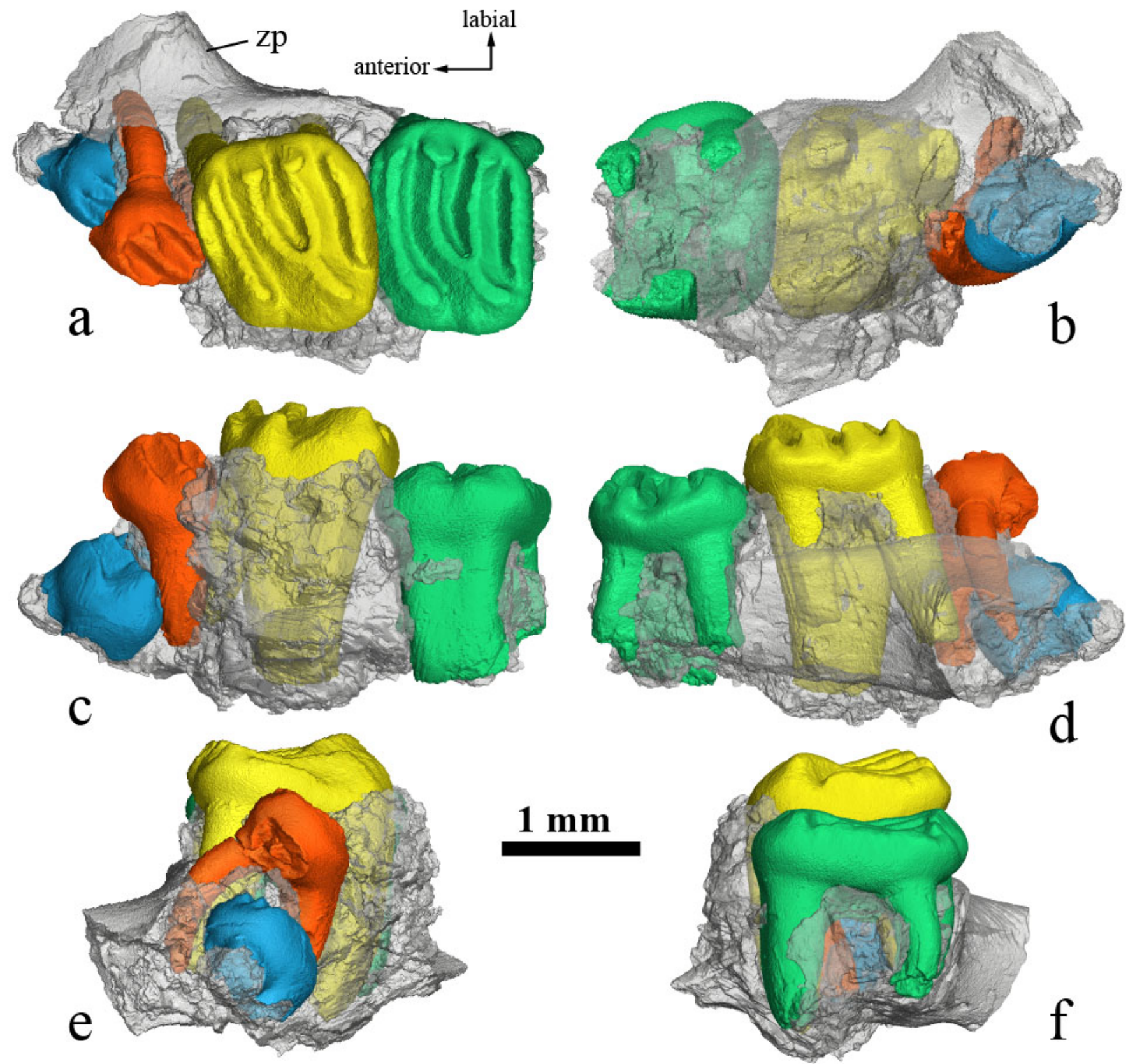

Figure 1. Maxilla MJSN-GLM017-0001, the holotype of Simplomys hugi with DP4 and P4-M2 in occlusal (a), dorsal (b), lingual (c), labial (d), anterior (e) and posterior (f) views. (blue, P4; red, DP4; yellow, M1; green, M2; zp, zygomatic process) 